\title{
Wastewater treatment from potato processing industry using Moringa Oleifera-based coagulant
}

Potato is the third most important food crop on the planet. The potato processing industry produces a variety of food products and has high effluent generation with high organic load and solids content. These must be treated before being disposed of in water bodies. One of the options for treatment of industrial effluents widely studied in the literature is the use of natural coagulants. In this context, this work aims to evaluate the efficiency of effluent treatment of a potato processing industry in Brazil through the use of coagulants based on Moringa Oleifera. Five flocculation essays (Jar Essay) were performed, evaluating the use of Moringa Oleifera both in direct use (flour crushed) and in saline solution, for different coagulant mass and volume values. Turbidity removal rates close to $93 \%$ were obtained when using Moringa Oleifera in saline as a coagulant, which is the most efficient use of Moringa seeds compared to their direct use. BOD (Biochemical Oxygen Demand) removal was also high, with values around $90 \%$. The Moringa planting area required for effluent treatment of the studied industry is 1.14 ha. The obtained results allowed the identification of the optimal coagulant dosages to be used and demonstrate the feasibility of using Moringa Oleifera to treat potato processing effluent.

Keywords: Moringa Oleifera; Potato processing industry; Effluent treatment; Coagulation; Flocculation.

\section{Tratamento de efluentes da indústria de processamento de batata usando coagulante à base de Moringa Oleifera}

\begin{abstract}
A batata é a terceira cultura alimentar mais importante do planeta. A indústria de processamento de batata produz uma variedade de produtos alimentícios e possui alta geração de efluentes com alta carga orgânica e teor de sólidos. Estes devem ser tratados antes de serem descartados em corpos d'água. Uma das opções para tratamento de efluentes industriais amplamente estudada na literatura é a utilização de coagulantes naturais. Nesse contexto, este trabalho tem como objetivo avaliar a eficiência do tratamento de efluentes de uma indústria processadora de batata no Brasil através do uso de coagulantes à base de Moringa Oleifera. Foram realizados cinco ensaios de floculação (Jar Essay), avaliando o uso da Moringa Oleifera tanto em uso direto (farinha triturada) quanto em solução salina, para diferentes valores de massa e volume de coagulante. Taxas de remoção de turbidez próximas a 93\% foram obtidas ao usar Moringa Oleifera em solução salina como coagulante, que é o uso mais eficiente das sementes de Moringa em comparação ao seu uso direto. A remoção de BOD (Biochemical Oxygen Demand) também foi alta, com valores em torno de $90 \%$. A área de plantio de Moringa necessária para tratamento de efluentes da indústria estudada é de 1,14 ha. Os resultados obtidos permitiram a identificação das dosagens ótimas de coagulante a serem utilizadas e demonstraram a viabilidade do uso da Moringa Oleifera no tratamento de efluente de processamento de batata.
\end{abstract}

Palavras-chave: Moringa Oleifera; Indústria de processamento de batata; Tratamento de efluentes; Coagulação; Floculação.

Topic: Engenharia Sanitária

Reviewed anonymously in the process of blind peer
Received: 03/07/2021

Approved: 28/07/2021
Ana Claudia Pinto Ferraz

Universidade Federal de Itajubá, Brasil

http://lattes.cnpq.br/2900805573838303

anaclaudiapintoferraz@gmail.com

Ivan Felipe Silva dos Santos

Universidade Federal de Itajubá, Brasil

http://lattes.cnpq.br/1175675008975515

ivanfelipedeice@hotmail.com

Athos Moisés Lopes Silva (iD)

Universidade Federal de Itajubá, Brasil

http://lattes.cnpq.br/1263676047246127

http://orcid.org/0000-0003-2565-8610

athos.ambiental@gmail.com

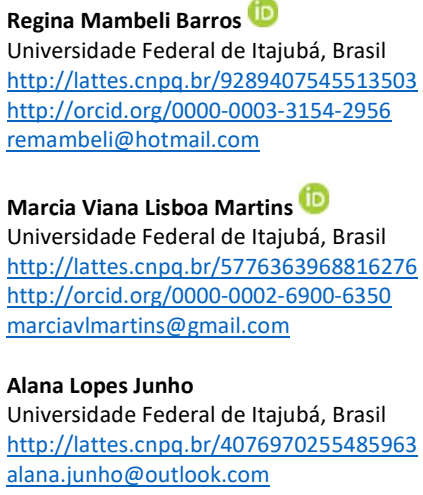

Referencing this:

FERRAZ, A. C. P.; SANTOS, I. F. S.; SILVA, A. M. L.; BARROS, R. M.; MARTINS, M. V. L.; JUNHO, A. L.. Wastewater treatment from potato processing industry using Moringa Oleifera-based coagulant. Revista Ibero Americana de Ciências Ambientais, v.12, n.7, p.211-224, 2021. DOI: http://doi.org/10.6008/CBPC2179-6858.2021.007.0020 


\section{INTRODUCTION}

The food industry has high levels of water consumption and effluent production per production unit (TIKARIHA et al., 2014). Among the various types of food industries, potato processing stands out. Potato (Solanum tuberosum L.) is the third most important food crop on the planet. It is estimated that over one billion people worldwide consume potatoes daily. Its annual world production exceeds 330 million tons in an area of 18 million hectares, and China and India are the main producers. The potato industry is a booming industry due to the versatility and composition of its products. Existing products include frozen and dehydrated, but it is the dehydrated grated potatoes and chips that are most marketed (CARVALHO, 2012).

In the Brazilian scenario, it is also of great importance and its productivity is on the rise, as both in natura and processed consumption increase. Currently the largest producing state in the Southeast is Minas Gerais, with southern Minas Gerais the largest planting area (AGRIANUAL, 2015). Like all industrial processes, the manufacture of grated potatoes and chips generates large amounts of waste, including potato peel, potato residual pulp and starch.

According to Moura (2013), in the processing of chips, water is widely used to wash the tubers from the beginning of the process until moments before the potato is sent to frying. A lot of water is used throughout the process, but the washing step after cutting is the most important, where the potato slices are washed with water jets or dipped to remove the starch released on the surface so to prevent them from sticking to each other during the frying process. In the case of grated potatoes, the washing process must be more careful, because there is greater starch release and the pieces are more fragile and more susceptible to breakage (TFOUNI et al., 2003). The figure 1 summarizes the process sequence of a conventional potato processing plant (HUNG et al., 2006). In this figure, we observe the need for water at various stages of the process. Water consumption varies depending on the type of product obtained from the potato, when it is between $11-22.55$ I of water per kg of product (WALKER et al., 2018).

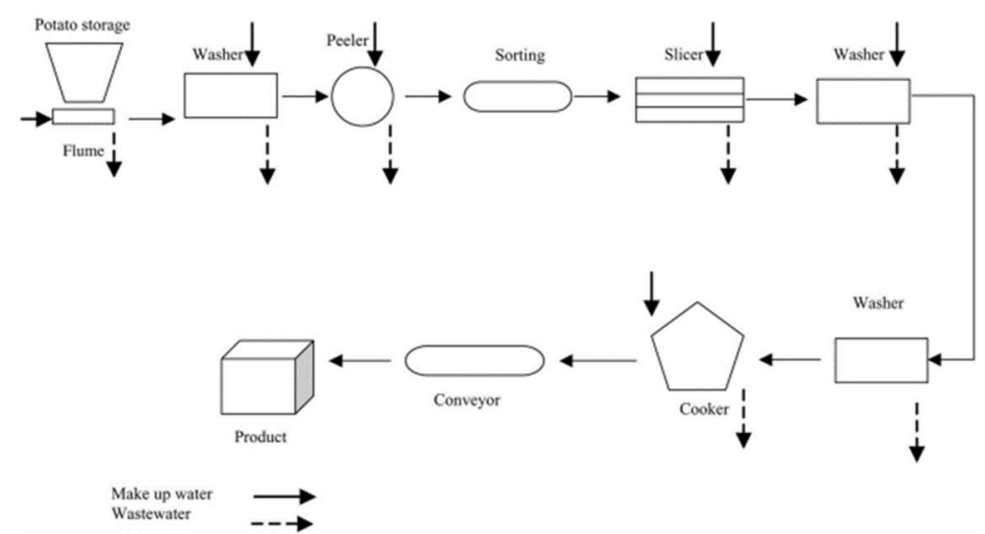

Figure 1: Scheme of a conventional potato processing plant. Source: Hung et al. (2006).

With intensive use of water in potato processing there is high generation of effluents. These effluents are characterized by a rich concentration of biodegradable compounds such as starch, proteins and also high suspended solids content (ZOUTBERG et al., 1999), with varying concentrations depending on the methods and the final processing product (HUNG et al., 2006). Therefore, several authors have studied the treatment 
of these effluents from the potato processing industry.

Authors such as Hadjivassilis et al. (1997) and Zoutberg et al. (1999) investigated the use of anaerobic and/or aerobic reactors for potato processing effluent treatment and they obtained high chemical oxygen demand removal (COD) efficiency values. Kobya et al. (2006) obtained high values of electrocoagulation removal, achieving high COD removal efficiency and turbidity when using aluminum electrodes, consuming $4 \mathrm{kWh} / \mathrm{m}^{3}$. Makwana et al. (2016) also apply electrocoagulation as an aftertreatment to anaerobic reactors, obtaining high efficiency not only in the treatment of COD and turbidity, but also in the reduction of fecal and total coliforms and phosphate.

More sophisticated treatments have also been suggested recently. Silva et al. (2016) suggest an alternative treatment for potato processing effluent pretreatment using solid catalysts for mineralization through heterogeneous photo-Fenton process using discarded pile ferrite. The effluent photodegradation results obtained showed a $32 \%$ solution mineralization efficiency during the initial 10 minutes. The authors conclude that these are quite interesting for the use of this process as pretreatment to conventional treatments. Radeef et al. (2019) treat these effluents with energy recovery using microbiological fuel cells, obtaining $90 \%$ removal efficiency of $90 \%$, with power of $97,5 \mathrm{~W} / \mathrm{m}^{2}$ in closed circuit.

One of the options for the sustainable treatment of industrial effluents is through natural productbased coagulants, such as Moringa Oleifera (MO) seed base (PAULA et al., 2014). Natural coagulants and flocculants, as MO (Moringa Oleifera), have shown advantages over chemicals, especially in relation to biodegradability and low production of residual sludge (MONACO et al., 2010). MO (Moringa Oleifera) is a perennial species of the Moringaceae family, originating from northeastern India (CORRÊA, 1984). It is a small tree, drought tolerant and fast growing, and adapts to a wide range of soils (CARDOSO et al., 2008). It is very hardy, grows in tropical warm and semi-arid climate at temperatures in the range of $25-35{ }^{\circ} \mathrm{C}$, can withstand up to $48^{\circ} \mathrm{C}$ for limited periods, and is drought tolerant (PRICE et al., 2000).

The coagulant action of $\mathrm{MO}$ (Moringa Oleifera) seed is due to the present fraction of high molecular weight cationic protein in its seeds, which causes destabilization of the particles contained in water and subsequent colloid coagulation (NDABIGENGESERE et al., 1995). These can be used directly in the form of flour or in aqueous, saline or more complex extracts, the coagulant extraction methodology and it is an influential treatment factor (VILLASEÑOR-BASULTO et al., 2018; ROCHA et al., 2019). However, Madrona et al. (2012) found that the protein concentration in the coagulant solution increases as the saline concentration increases. According to Valverde et al. (2013), MO (Moringa Oleifera), unlike metal-based chemical coagulants, acts over a large $\mathrm{pH}$ range and does not significantly change the $\mathrm{pH}$ of treated water. $\mathrm{MO}$ (Moringa Oleifera) has several other applications besides coagulant effect, such as food source and medicinal function, industrial use for obtaining biodiesel oil and agronomic use (RANGEL, 1999; LIU et al., 2018; FERNANDES et al., 2019). Oil obtained from seeds has no toxic effects (KAYODE et al., 2015).

Studies of MO (Moringa Oleifera) applications for industrial effluent treatment are abundant in the literature, including treatment of dairy effluent, distilleries, textile industries, heavy metals, food industry, among others, and a complete review on the subject can be obtained in Villaseñor-Basulto et al. (2018). 
However, no studies are found in the literature for the effluent treatment of the potato processing industry using MO (Moringa Oleifera).

In this context, the objective of the present work is to evaluate the efficiency of MO-based coagulants in the treatment of turbidity and effluent COD (Chemical Oxygen Demand) from the potato processing industry, under different coagulant preparation and dosage methodologies. Comparison with traditional commercial coagulants such as ferric chloride and aluminum sulfate are also performed. Finally, the required planting area and the technical feasibility of applying Moringa Oleifera in a potato processing industry in Brazil is discussed.

\section{METHODOLOGY}

As it was previously mentioned, the coagulant used in the treatment is organic based and was produced by using Moringa Oleifera seeds in direct application and use in saline solution. There are no applications in literature so far of the use of Moringa Oleifera for treatment of this type of effluent. Figure 2 briefly shows the steps for performing the experiments in this article. The main steps in this figure are presented in later topics. After evaluation of the treatment efficiency, an estimate of the necessary planting area for the application of $\mathrm{MO}$ (Moringa Oleifera) seeds for effluent treatment of a potato processing industry was performed.

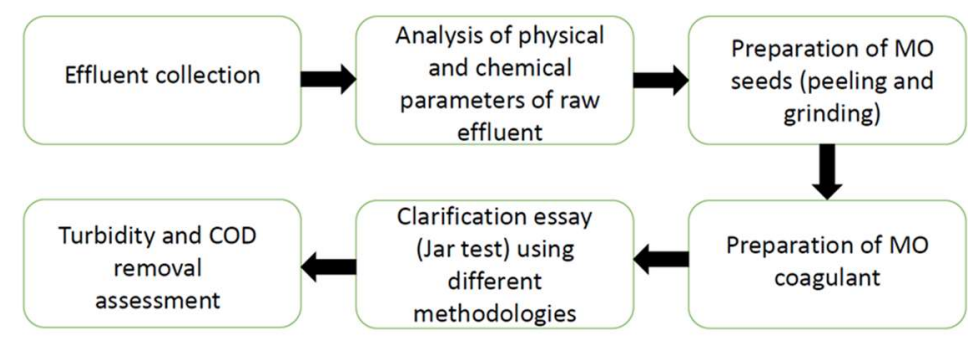

Figure 2: Flowchart of laboratory steps.

\section{Effluent collection and characterization}

The effluent used for this experiment comes from the potato processing industry of the city of Maria da Fé, located in the south of Minas Gerais state, Brazilian state with the largest potato production. Although sparsely populated (14.646 inhabitants), the city has a preponderance in potato processing and has seven factories. The correct treatment of these effluents is essential to minimize the impact on the environment.

In all, 5 trials were carried out with a total consumption of 50 liters of effluent, and this volume does not belong to the same sampling day, varying according to the potato processing days and laboratory dates. The essays were performed at the Sanitation Laboratory of the Federal University of Itajubá, Brazil. For the initial characterization of the effluent, the measurement methodologies presented in Standard Methods for Examination for the Examination of Water and Wastewater (APHA, 2012) were followed. Table 1 indicates the procedure used to determine the parameters. 
Table 1: Physicochemical parameters measured in the samples.

\begin{tabular}{|c|c|}
\hline Parameters & Methodology \\
\hline pH & PH reading by pH meter (Model: Digimed DM - $220 \mathrm{~V}$ ) \\
\hline Turbidity & Turbidity Reading by Digital Turbidity Meter (Model: PoliControl AP2000) \\
\hline Conductivity & Conductivity Reading by Conductivity Meter \\
\hline COD & $\begin{array}{l}1.5 \mathrm{ml} \mathrm{K} 2 \mathrm{Cr} 207 \text { was added; } 3.5 \mathrm{ml} \mathrm{H} 2 \mathrm{SO} 4 \text { and } 2.5 \mathrm{ml} \mathrm{sample.} \\
\text { The sample was taken to the digester for } 2 \text { hours at } 150^{\circ} \mathrm{C} \text { and then it was read on the } \\
\text { spectrophotometer. }\end{array}$ \\
\hline $\begin{array}{l}\text { BOD (Biochemical Oxygen } \\
\text { Demand) }\end{array}$ & $\begin{array}{l}\text { The dissolved oxygen concentration (initial OD) in the sample was measured. Then the sample } \\
\text { was sealed and kept in an oven for five days at } 20^{\circ} \mathrm{C} \text { in an amber vial and the } \mathrm{pH} \text { adjusted to } \\
\text { neutral. At the end of the five days, the measurement of dissolved oxygen (final DO) was } \\
\text { repeated. BOD (Biochemical Oxygen Demand) was given by the difference between the initial } \\
\text { OD and the final OD }\end{array}$ \\
\hline
\end{tabular}

\section{Preparation of MO (Moringa Oleifera) and Coagulant Seeds}

In the experiments of this work, coagulants prepared from MO (Moringa Oleifera) seed were used in two forms: crushed (direct use) and in saline solution. According to Arantes et al. (2012), MO (Moringa Oleifera) flour with a small particle size, reduces some lipids that are present in seeds, also reducing turbidity and apparent color when flour is used in water treatment processes. The procedure for applying this alternative was as follows: i) Seed husk removal; ii) Store in an oven at 150 ㅇ $\mathrm{C}$ for 24 hours for drying; iii) Crushing the seeds with the support of a mixer for 15 minutes; and iv) Maintaining seeds in a desiccator.

The preparation of the MO (Moringa Oleifera) solution in saline solution was adapted from the methodology applied by Madrona et al. (2012), applying the following procedure: i) Preparation of a $1 \mathrm{~mol} / \mathrm{L}$ $\mathrm{NaCl}$ solution; (ii) Weighing of crushed and blended Moringa Oleifera pasta; (iii) homogenization of seed powder with $100 \mathrm{ml}$ of saline solution; iv) Rest of solution for 24 hours.

From the fourth essay two commercial coagulants were used to compare with the natural coagulant, aluminum sulfate $\left(\mathrm{Al}_{2}\left(\mathrm{SO}_{4}\right)_{3}\right)$ and ferric chloride $\left(\mathrm{FeCl}_{3}\right)$.

\section{Coagulation Essay Methodology (Jar Test)}

Five Jar Tests were performed to evaluate the efficiency of coagulation and flocculation in the effluent treatment. In each of the trials, five $1.5 \mathrm{~L}$ effluent jars and different coagulant volumes were used. Table 2 presents the methodology and the main aspects of each of the essays studied. Table 2 shows that the methodology composition in the different essays was quite diverse and several parameters were varied from one essay to another, or even within a single essay in the different jars employed. This resulted from the fact that the application proposed by the authors has been innovative in the literature so far, seeing that the information on which the authors could base their studies was scarce, leading the authors to define the condition of each new essay based on the results of the previous study, in order to find the best coagulant preparation methodology as well as to improve its coagulant dosage.

For the first four essays the following coagulation parameters were applied in the Jar Test: i) Rapid Mixing: Rotation of 200 RPM for 60 seconds; ii) Slow Mix: 100 RPM rotation for 40 minutes; and iii) Sedimentation: 60 minutes for sediment deposition (same parameters applied by VIEIRA et al., 2009; JUNHO 
et al., 2021). In order to achieve greater efficiency, higher values of coagulation parameters used in the treatment of high organic wastewater were applied to the fifth essay. The values for thisessay were: i) Rapid Mix: 480 RPM rotation for 60 seconds; ii) Slow Mix: Spin at 54 RPM for 10 minutes; iii) Sedimentation: 20 minutes for sediment deposition.

Table 2: Summary of the methodology applied to each essay.

\begin{tabular}{|c|c|c|c|}
\hline Essays & Coagulant Type & $\begin{array}{ll}\text { Mass } & \text { or } \\
\text { volume } & \text { of } \\
\text { coagulant } & \text { in } \\
\text { each jar } & \\
\end{array}$ & Justification \\
\hline \multirow{5}{*}{ I } & \multirow{5}{*}{$\begin{array}{l}\text { MO (Moringa Oleifera) ground } \\
\text { into flour }\end{array}$} & $\begin{array}{l}\text { Jar1: } 0,5 \mathrm{~g} \text { of } \\
\text { coagulant }\end{array}$ & \multirow{5}{*}{$\begin{array}{l}\text { The MO (Moringa Oleifera) masses used in each jarwere arbitrarily } \\
\text { chosen, initially taking lower values in order to understand the } \\
\text { effluent behavior with the addition of the coagulant mass. }\end{array}$} \\
\hline & & $\begin{array}{l}\text { Jar2: } 0,75 \mathrm{~g} \text { of } \\
\text { coagulant }\end{array}$ & \\
\hline & & $\begin{array}{l}\text { Jarr } 3: 1 \mathrm{~g} \text { of } \\
\text { coagulant }\end{array}$ & \\
\hline & & $\begin{array}{l}\text { Jar4: } 1,5 \mathrm{~g} \text { of } \\
\text { coagulant }\end{array}$ & \\
\hline & & $\begin{array}{l}\text { Jar5: } 2 \mathrm{~g} \text { of } \\
\text { coagulant }\end{array}$ & \\
\hline \multirow{5}{*}{ II } & \multirow{3}{*}{$\begin{array}{l}\text { MO (Moringa Oleifera) in saline } \\
\text { that was prepared using } 3 g \text { of } \\
\text { seed }\end{array}$} & $\begin{array}{l}\text { Jar1: } 10 \mathrm{ml} \text { of } \\
\text { coagulant }\end{array}$ & \multirow{5}{*}{$\begin{array}{l}\text { The increase of the crushed MO (Moringa Oleifera) mass in } \\
\text { relation to the previous essay was performed aiming to analyze an } \\
\text { optimal maximum value of efficiency in this type of application. } \\
\text { Saline MO (Moringa Oleifera) was also tested with arbitrarily } \\
\text { determined increasing coagulant volumes }\end{array}$} \\
\hline & & $\begin{array}{l}\text { Jar2: } 20 \mathrm{ml} \text { of } \\
\text { coagulant }\end{array}$ & \\
\hline & & $\begin{array}{l}\text { Jar3: } 30 \mathrm{ml} \text { of } \\
\text { coagulant }\end{array}$ & \\
\hline & $\begin{array}{l}\text { MO (Moringa Oleifera) ground } \\
\text { into flour }\end{array}$ & $\begin{array}{l}\text { Jar4: } 3 \mathrm{~g} \text { of } \\
\text { coagulant }\end{array}$ & \\
\hline & The jarwas not used & - & \\
\hline \multirow{5}{*}{ III } & \multirow{2}{*}{$\begin{array}{l}\mathrm{MO} \text { (Moringa Oleifera) in saline } \\
\text { solution that was prepared using } \\
6 \mathrm{~g} \text { of seed }\end{array}$} & $\begin{array}{l}\text { Jar 1: } 40 \mathrm{ml} \text { of } \\
\text { coagulant }\end{array}$ & \multirow[t]{5}{*}{$\begin{array}{l}\text { Third essay: adaptation of the second essay, seeking greater } \\
\text { efficiency in results by greater use of mass and seeds. }\end{array}$} \\
\hline & & $\begin{array}{l}\text { Jar 2: } 60 \mathrm{ml} \text { of } \\
\text { coagulant }\end{array}$ & \\
\hline & $\begin{array}{l}\text { MO (Moringa Oleifera) was } \\
\text { ground into flour }\end{array}$ & $\begin{array}{l}\text { Jarro } 3: 8 \mathrm{~g} \text { of } \\
\text { coagulant }\end{array}$ & \\
\hline & \multirow{2}{*}{ The jars were not used } & - & \\
\hline & & - & \\
\hline \multirow{5}{*}{ IV } & \multirow[t]{2}{*}{$\begin{array}{l}\text { Use of Commercial Ferric } \\
\text { Chloride Coagulant }\left(\mathrm{FeCl}_{3}\right)\end{array}$} & $\begin{array}{l}\text { Jar } 1: 7,5 \mathrm{ml} \text { of } \\
\text { coagulant }\end{array}$ & \multirow{5}{*}{$\begin{array}{l}\text { From the fourth trial, we sought to verify the effectiveness of } \\
\text { conventional treatment with coagulants based on MO (Moringa } \\
\text { Oleifera), also evaluate the use of commercial coagulants and } \\
\text { compare which has greater efficiency in treatment. }\end{array}$} \\
\hline & & $\begin{array}{l}\text { Jar } 2: 11,25 \mathrm{ml} \\
\text { of coagulant }\end{array}$ & \\
\hline & $\begin{array}{l}\mathrm{MO} \text { (Moringa Oleifera) ground } \\
\text { into flour }\end{array}$ & $\begin{array}{l}\text { Jar 3: } 16 \mathrm{~g} \text { of } \\
\text { coagulant }\end{array}$ & \\
\hline & \multirow[t]{2}{*}{ The jar was not used } & - & \\
\hline & & - & \\
\hline \multirow{5}{*}{$\mathbf{v}$} & $\begin{array}{l}\text { MO(Moringa Oleifera) in saline } \\
\text { solution using } 15 \mathrm{~g} \text { of seeds, } \\
\text { filtered using } 40[\mu] \text { sheet paper } \\
\text { and correcting the } \mathrm{pH} \text { of the } \\
\text { solution until reaching } \mathrm{pH} 7.0\end{array}$ & $\begin{array}{l}\text { Jarro } 1: 50 \mathrm{ml} \\
\text { of coagulant }\end{array}$ & \multirow{5}{*}{$\begin{array}{l}\text { The filtration to remove moringa powder residues in saline } \\
\text { solution was performed to verify the influence of these residues } \\
\text { on the treated effluent turbidity. } \\
\text { The potato effluent has a more acidic } \mathrm{pH} \text {, so it was decided to } \\
\text { leave the neutral } \mathrm{pH} \text { by adding sodium hydroxide }(\mathrm{NaOH})(10 \mathrm{~g} / \mathrm{l}) \text {, } \\
\text { In order to improve the treatment efficiency. Another commercial } \\
\text { coagulant, besides ferric chloride was evaluated, aluminum } \\
\text { sulfate. In this last essay, BOD (Biochemical Oxygen Demand) and } \\
\text { COD (Chemical Oxygen Demand) were also analyzed. }\end{array}$} \\
\hline & \multirow{2}{*}{ Ferric chloride $\left(\mathrm{FeCl}_{3}\right)$} & $\begin{array}{l}\text { Jar 2: } 18.75 \mathrm{ml} \\
\text { of coagulant }\end{array}$ & \\
\hline & & $\begin{array}{l}\text { Jar 3: } 22.5 \mathrm{ml} \\
\text { of coagulant }\end{array}$ & \\
\hline & Aluminum sulfate $\left(\mathrm{Al}_{2}\left(\mathrm{SO}_{4}\right)_{3}\right)$ & $\begin{array}{l}\text { Jar } 4: 18.75 \mathrm{ml} \\
\text { of coagulant }\end{array}$ & \\
\hline & The jar was not used & - & \\
\hline
\end{tabular}




\section{Estimated MO (Moringa Oleifera) planting area required to service a potato processing plant in Brazil}

In order to analyze the planting area and mass of MO (Moringa Oleifera) seeds that will be spent to attend the effluent treatment of the potato processing plant from which the samples were collected, it was adopted a yield of MO (Moringa Oleifera) seed production by tree with $24 \mathrm{~kg} /$ year (Moringa Brazil, 2012) and a number of trees per hectare of 2000 (AYERZA, 2012). These are the same values used by Rocha et al. (2019). The effluent production from the industry assessed is approximately $30,000 \mathrm{l} / \mathrm{d}$, with 20 production days per month. The mass of MO (Moringa Oleifera) seed consumed in $\mathrm{kg} / \mathrm{year}$ was calculated based on the mass per I of sample used to prepare the saline solution for the highest turbidity removal essay.

\section{RESULTS AND DISCUSSON}

\section{Laboratory results}

The table 3 indicates the initial characteristics of the raw effluent for the samples used in each of the fiveessays, respectively. It is noteworthy that the samples were not collected on the same day, which justifies the differences in their characteristics.

Table 3: Initial characteristics of the analyzed effluent.

\begin{tabular}{|l|l|l|l|l|l|l|}
\hline Parameter & Sample 1 & Sample 2 & Sample 3 & Sample 4 & Sample 5 & Average \\
\hline pH at 25o & 5.44 & 5.39 & 5.65 & 5.18 & 5.54 & $5.54 \pm 0.18$ \\
\hline Turbidity (NTU- Nephelometric Turbidity Unity) & 570 & 483 & 521 & 573 & 1101 & $649.6 \pm 255.1$ \\
\hline Conductivity (mS/cm) & 1.69 & 2.24 & 3.81 & 5 & 2.31 & $3.01 \pm 1.37$ \\
\hline
\end{tabular}

It can be seen from table 3 that the $\mathrm{pH}$ of the sample is generally acidic. There is also a high turbidity variation between the first 4 samples and the last one, which may be explained by a higher solids loading in the washed potatoes on this day. Table 4 indicates the results obtained in the first trial.

Table 4: First Essay: Final Result of Treated Effluent.

\begin{tabular}{|l|l|l|l|l|l|}
\hline $\begin{array}{l}\text { Jar } \\
\mathbf{s}\end{array}$ & $\begin{array}{l}\text { Moringa mass } \\
\text { used in g }\end{array}$ & $\begin{array}{l}\text { Final } \\
\text { pH }\end{array}$ & $\begin{array}{l}\text { Final Turbidity in NTU (Nephelometric } \\
\text { Turbidity Unity) }\end{array}$ & $\begin{array}{l}\text { Turbidity Removal } \\
\text { Efficiency }\end{array}$ & $\begin{array}{l}\text { Final Conductivity in } \\
\mathbf{m s} / \mathbf{c m}\end{array}$ \\
\hline $\begin{array}{l}\operatorname{Jar} \\
1\end{array}$ & 0.5 & 5.53 & 519 & $8.95 \%$ & 4.85 \\
\hline $\begin{array}{l}\operatorname{Jar} \\
2\end{array}$ & 0.75 & 5.61 & 502 & $11.93 \%$ & 4.71 \\
\hline $\begin{array}{l}\operatorname{Jar} \\
3\end{array}$ & 1 & 5.63 & 331 & $41.93 \%$ & 2.06 \\
\hline $\begin{array}{l}\operatorname{Jar} \\
4\end{array}$ & 1.5 & 5.68 & 318 & $44.21 \%$ & 1.91 \\
\hline $\begin{array}{l}\operatorname{Jar} \\
5\end{array}$ & 2 & 5.69 & 295 & $48.25 \%$ & 1.91 \\
\hline
\end{tabular}

From the results obtained, regarding turbidity, it can be concluded that the MO (Moringa Oleifera) powder masses used were not the most effective for the treatment of this effluent, seeing that the removal efficiency for none of the 5 jars was if above $50 \%$. Jar 5 , which used the highest MO (Moringa Oleifera) mass, was the one that obtained the largest turbidity reduction, which indicates the need for a higher $\mathrm{MO}$ (Moringa Oleifera) mass.

As for the $\mathrm{pH}$, as expected, the $\mathrm{MO}$ (Moringa Oleifera) tends not to modify it, keeping in the same range of the initial value, and the small changes in the $\mathrm{pH}$ occurred with the gradual increase of the moringa 
mass. The effluent temperature, before and after the addition of Moringa, remained between $25 \circ \mathrm{C}$ and $26^{\circ} \mathrm{C}$, so it can be said that for these concentrations, the moringa does not remove or print heat in the solution that acts. Conductivity was high in all jars, especially those with low turbidity removal efficiency, probably due to the absence of coagulation reaction.

The Table 5 presents the results of the second essay. It was tested, in addition to the higher mass $\mathrm{MO}$ (Moringa Oleifera) flour, the $\mathrm{MO}$ (Moringa Oleifera) in saline prepared using $3 \mathrm{~g} \mathrm{MO}$ (Moringa Oleifera) (see table 2). It is noted that all essays were able to obtain high turbidity removal values, with percentages above $50 \%$. The saline solution had a higher turbidity removal, explained by the fact that the moringa's particles were more dissolved and in smaller flakes, allowing for the most efficient coagulation process. The highest turbidity removal efficiencies were in the use of Saline Solution (30 $\mathrm{ml}$ - Jar 3).

Table 5: Second Essay: Final Result of Treated Effluent.

\begin{tabular}{|c|c|c|c|c|c|c|}
\hline $\begin{array}{l}\text { Ja } \\
\text { rs }\end{array}$ & Coagulant Items & $\begin{array}{l}\text { Coagulant } \\
\text { mass/volume }\end{array}$ & $\begin{array}{l}\text { Final } \\
\text { pH }\end{array}$ & $\begin{array}{l}\text { Final Turbidity in NTU } \\
\text { (Nephelometric Turbidity Unity) }\end{array}$ & $\begin{array}{l}\text { Turbidity } \\
\text { Removal } \\
\text { Efficiency }\end{array}$ & $\begin{array}{l}\text { Final } \\
\text { Conductivity in } \\
\mathrm{mS} / \mathrm{cm}\end{array}$ \\
\hline $\begin{array}{l}\mathrm{Ja} \\
\mathrm{r} 1\end{array}$ & \multirow{3}{*}{ Saline solution in $\mathrm{ml}$} & 10 & 5.42 & 101 & $79.09 \%$ & 2.63 \\
\hline $\begin{array}{l}\mathrm{Ja} \\
\mathrm{r} 2\end{array}$ & & 20 & 5.43 & 96 & $80.12 \%$ & 2.79 \\
\hline $\begin{array}{l}\mathrm{Ja} \\
\mathrm{r} 3\end{array}$ & & 30 & 5.45 & 85 & $82.40 \%$ & 3.06 \\
\hline $\begin{array}{l}\mathrm{Ja} \\
\mathrm{r} 4\end{array}$ & $\begin{array}{ll}\text { MO } & \text { (Moringa } \\
\text { Oleifera) ground in } \mathrm{g}\end{array}$ & 5 & 5.55 & 140 & $71.01 \%$ & 4.55 \\
\hline
\end{tabular}

Again, the $\mathrm{pH}$ of the sample did not change at the end of the process and its temperature remained at approximately $25{ }^{\circ} \mathrm{C}$, which characterizes an advantage of $\mathrm{MO}$ (Moringa Oleifera). The conductivities in the saline samples increased with increasing volume, and the conductivity in the crushed MO (Moringa Oleifera) direct use sample was the highest among all worked. This can be explained by the diameter and particle composition of Moringa powder. The favorable results from the second essay indicate that an increased use of $\mathrm{MO}$ (Moringa Oleifera) may lead to even more positive results, which led to the completion of the third trial.

Table 6 sets out the results obtained in the third trial. This maintained the same logic as the second trial, comparing the use of $\mathrm{MO}$ (Moringa Oleifera) in saline, now more concentrated and prepared $6 \mathrm{~g}$ seed (double from the previous trial), and used directly ground.

Table 6: Third Essay: Final Result of Treated Effluent.

\begin{tabular}{|l|l|l|l|l|l|l|}
\hline $\begin{array}{l}\text { Jar } \\
\text { S }\end{array}$ & $\begin{array}{l}\text { Coagulant } \\
\text { Items }\end{array}$ & $\begin{array}{l}\text { Coagulant } \\
\text { mass/volume }\end{array}$ & $\begin{array}{l}\text { Final } \\
\text { pH }\end{array}$ & $\begin{array}{l}\text { Final Turbidity in NTU } \\
\text { (Nephelometric Turbidity Unity) }\end{array}$ & $\begin{array}{l}\text { Turbidity Removal } \\
\text { Efficiency }\end{array}$ & $\begin{array}{l}\text { Final Conductivity } \\
\text { in mS/cm }\end{array}$ \\
\hline $\begin{array}{l}\text { Jar } \\
1\end{array}$ & $\begin{array}{l}\text { Saline } \\
\text { solution in } \\
\text { ml }\end{array}$ & 40 & 5.69 & 90 & $82.73 \%$ & 5.9 \\
\cline { 2 - 7 } \begin{tabular}{l} 
Jar \\
\cline { 2 - 7 } \\
3
\end{tabular} & 60 & 5.67 & 89 & $82.92 \%$ & 6.54 \\
\hline
\end{tabular}

For the third trial, all jars showed more than $80 \%$ turbidity removal, but the sample from Jar 3 , with direct use of crushed MO (Moringa Oleifera) was the most efficient. For saline MO (Moringa Oleifera), there is a small increase in efficiency, around $0.19 \%$, between jars 1 and 2 , despite the large increase in the volume 
of coagulant used $(20 \mathrm{ml}$ or $50 \%)$ and a certain increase conductivity of the sample. This indicates a stabilization trend, that is, the use of more concentrated solutions or larger volumes will not lead to high turbidity removal gains. The direct use of moringa powder is still efficient, with increasing percentage of turbidity removal between masses of $5 \mathrm{~g}$ (second essay - 71\%) and $8 \mathrm{~g}$ ( $85 \%$ - third essay), which demonstrates that unlike saline, $\mathrm{MO}$ (Moringa Oleifera) still does not tend to stabilize. The $\mathrm{pH}$ remained in the same range as the initial $\mathrm{pH}$, as expected, and the temperature did not vary, as in the other essays.

The results obtained in all three demonstrate the effectiveness of the effluent treatment of the potato processing industry from MO (Moringa Oleifera), both in saline and crushed powder. It is noteworthy that although consuming a higher amount of gm of $\mathrm{MO}$ (Moringa Oleifera) seed, direct use in 8g was more efficient than the use of saline solution with $6 \mathrm{~g}$ of $\mathrm{MO}$ (Moringa Oleifera) and not consuming water or salt in the preparation of coagulant.

Subsequent trials ( 4 and 5 ) focus on comparing the good results already obtained with MO (Moringa Oleifera) coagulants with those of commercial coagulants. Essay 4 compared the use of ferric chloride with direct use of $\mathrm{MO}$ (Moringa Oleifera) with twice the mass used in essay 3, seeing that no tendency to stabilize turbidity removal in this type of coagulant was observed. The results of the fourth trial are presented by Table 7.

Table 7: Fourth Essay: Final Result of Treated Effluent.

\begin{tabular}{|l|l|l|l|l|l|l|l|}
\hline $\begin{array}{l}\text { Jar } \\
\text { S }\end{array}$ & $\begin{array}{l}\text { Coagulant } \\
\text { items }\end{array}$ & $\begin{array}{l}\text { Coagulant } \\
\text { mass/volume }\end{array}$ & $\begin{array}{l}\text { Final } \\
\text { pH }\end{array}$ & $\begin{array}{l}\text { Final Turbidity in NTU } \\
\text { (Nephelometric Turbidity Unity) }\end{array}$ & $\begin{array}{l}\text { Turbidity Removal } \\
\text { Efficiency }\end{array}$ & $\begin{array}{l}\text { Final Conductivity } \\
\text { in mS/cm }\end{array}$ \\
\hline $\begin{array}{l}\text { Jar } \\
1\end{array}$ & \multirow{2}{*}{$\mathrm{FeCl}_{3}$ in $\mathrm{ml}$} & 7.5 & 5.09 & 566 & $1.22 \%$ & 4.89 \\
\cline { 2 - 7 } \begin{tabular}{l}
$\mathrm{Jar}$ \\
\cline { 2 - 7 }
\end{tabular} & 11.25 & 5.12 & 555 & $3.14 \%$ & 4.66 \\
\hline \begin{tabular}{l} 
Jar \\
\cline { 2 - 7 }
\end{tabular} & $\begin{array}{l}\text { Moringa in } \\
\mathrm{g}\end{array}$ & 16 & 5.03 & 900 & $-57.07 \%$ & 4.78 \\
\hline
\end{tabular}

This essay was the one that presented the lowest efficiency with regard to Turbidity removal. Ferric Chloride concentrations taken from Silva et al. (2007) methodology proved ineffective for coagulation. In addition, the direct application of Moringa, evident in jar3, with a mass of MO (Moringa Oleifera) equal to twice the previous essay, eventually increased the turbidity of the sample, by reason of being present in an excessive concentration which inhibited the coagulation reaction and increased the concentration of suspended solids in the effluent. Thus a value $(16 \mathrm{~g})$ was found for which it was no longer recommended to use the direct application of Moringa powder.

The table 8 shows the results obtained in the fifth and last trial. In this trial, the MO (Moringa Oleifera) coagulant was compared with two commonly used commercial coagulants in Brazil, ferric chloride (normally used for sewage treatment) and aluminum sulfate (used for water treatment). As aluminum sulfate has its optimal operation near neutral $\mathrm{pH}$, the $\mathrm{pH}$ was adjusted in all samples. We know that the authors had already come to a conclusion regarding the use of direct MO (Moringa Oleifera) in trials 3 and 4, thisessay was performed with more concentrated saline ( $15 \mathrm{~g}$ of $\mathrm{MO}$ - Moringa Oleifera) carefully filtered to remove any residual MO (Moringa Oleifera) dust (see table 2). The coagulant volume used was the intermediate between the optimal volumes identified inessay 3. 
Table 8: Fifth Essay: Final Result of Treated Effluent.

\begin{tabular}{|l|l|l|l|l|l|l|}
\hline $\begin{array}{l}\text { Jar } \\
\text { S }\end{array}$ & $\begin{array}{l}\text { Coagulant } \\
\text { Items }\end{array}$ & $\begin{array}{l}\text { Concentr } \\
\text { ation }\end{array}$ & $\begin{array}{l}\text { Final } \\
\text { pH }\end{array}$ & $\begin{array}{l}\text { Final Turbidity in NTU (Nephelometric } \\
\text { Turbidity Unity) }\end{array}$ & $\begin{array}{l}\text { Turbidity Removal } \\
\text { Efficiency }\end{array}$ & $\begin{array}{l}\text { Final Conductivity } \\
\text { in } \mathbf{m S} / \mathbf{c m}\end{array}$ \\
\hline $\begin{array}{l}\text { Jar } \\
1\end{array}$ & \multirow{2}{*}{$\mathrm{FeCl}_{3}$ in $\mathrm{ml}$} & 18.75 & 6.79 & 560 & $49.14 \%$ & 2.55 \\
\cline { 2 - 7 } $\begin{array}{l}\mathrm{Jar} \\
2\end{array}$ & 22.5 & 6.73 & 699 & $36.51 \%$ & 2.58 \\
\hline $\begin{array}{l}\text { Jar } \\
3\end{array}$ & $\begin{array}{l}\text { Saline } \\
\text { solution in ml }\end{array}$ & 50 & 6.96 & 70 & $93.64 \%$ & 2.2 \\
\hline $\begin{array}{l}\text { Jar } \\
4\end{array}$ & $\begin{array}{l}\mathrm{Al}_{2}\left(\mathrm{SO}_{4}\right) 3 \text { in } \\
\mathrm{ml}\end{array}$ & 18.75 & 6.67 & 311 & $71.75 \%$ & 2.31 \\
\hline
\end{tabular}

It can be seen from table 8 that turbidity removal efficiency was less than $80 \%$ in all use cases of commercial metal based coagulants. Only in the case of saline solution was obtained a removal efficiency greater than $90 \%$, the highest value obtained in the present work. This behavior can be explained by the following factors: saline filtration, change in coagulation parameters or greater initial turbidity of sample 5 (see table 2).

The addition of $\mathrm{FeCl}_{3}$ formed a by-product that changed the effluent shade to a dark green to black color. This byproduct may be the result of a reaction between the Iron chloride chloride ion and a dissociated sodium metabisulfite ion $\left(\mathrm{Na}_{2} \mathrm{~S}_{2} \mathrm{O}_{5}\right)$, an inorganic compound released in the preparation of potato chips with antioxidant/preservative function, forming a by-product of bronze color tending to black. Another explanation is that Ferric Chloride may have been released at a higher concentration than the effluent dilution capacity, because $\mathrm{FeCl}_{3}$ prepared as a coagulant also has a dark color, characteristic of Iron, and it is an insoluble compound in organic solvents, the contact of a high concentration with the starch present in the effluent, and it may have caused the generation of dark colored byproducts.

Seeing that this was the highest turbidity removal efficiency essay, the COD (Chemical Oxygen Demand) removal efficiency of the coagulation process was also evaluated (Table 9). While the commercial coagulants showed no efficiency of removal of these parameters, the efficiency of removal of organic load of the saline solution of MO (Moringa Oleifera) was high, presenting values above $80 \%$ for both BOD (Biochemical Oxygen Demand) and COD (Chemical Oxygen Demand), which characterizes it as a viable treatment option from the potato processing industry. This value complies with Resolution 430/2011 of the National Environmental Council (CONAMA, 2011) which stipulates a minimum BOD (Biochemical Oxygen Demand) reduction efficiency of $70 \%$ for effluent disposal in Brazilian water sources.

Table 9: Fifth Essay: COD (Chemical Oxygen Demand) and BOD (Biochemical Oxygen Demand) for Raw and Treated Effluent.

\begin{tabular}{|c|c|c|c|c|c|c|c|}
\hline $\begin{array}{l}J \\
a \\
r \\
s\end{array}$ & $\begin{array}{l}\text { Coagu } \\
\text { lant } \\
\text { Items }\end{array}$ & $\begin{array}{l}\text { Initial COD } \\
\text { (Chemical } \\
\text { Oxygen } \\
\text { Demand) in } \\
\mathrm{mg} / \mathrm{l} \\
\end{array}$ & $\begin{array}{l}\text { Final COD } \\
\text { (Chemical } \\
\text { Oxygen } \\
\text { Demand) in } \\
\mathrm{mg} / \mathrm{L} \\
\end{array}$ & $\begin{array}{l}\text { COD (Chemical } \\
\text { Oxygen } \\
\text { Demand) } \\
\text { removal } \\
\text { efficiency }\end{array}$ & $\begin{array}{l}\text { Initial BOD } \\
\text { (Biochemical } \\
\text { Oxygen } \\
\text { Demand) in } \\
\mathrm{mg} / \mathrm{l} \\
\end{array}$ & $\begin{array}{l}\text { Final BOD } \\
\text { (Biochemical } \\
\text { Oxygen } \\
\text { Demand) mg/l }\end{array}$ & $\begin{array}{l}\text { BOD (Biochemical } \\
\text { Oxygen Demand) } \\
\text { Removal } \\
\text { Efficiency }\end{array}$ \\
\hline $\begin{array}{l}J \\
a \\
r \\
1\end{array}$ & $\mathrm{FeCl}_{3}$ & 2580 & 2450 & $5 \%$ & 1747 & N/A & N/A \\
\hline $\begin{array}{l}J \\
a \\
r \\
2\end{array}$ & in $\mathrm{ml}$ & 2580 & 2670 & $-3 \%$ & 1747 & N/A & N/A \\
\hline
\end{tabular}




\begin{tabular}{|c|c|c|c|c|c|c|c|}
\hline $\begin{array}{l}\mathrm{J} \\
\mathrm{a} \\
\mathrm{r} \\
3 \\
\end{array}$ & $\begin{array}{l}\text { Saline } \\
\text { soluti } \\
\text { on in } \\
\mathrm{ml}\end{array}$ & 2580 & 468 & $82 \%$ & 1747 & 188 & $89 \%$ \\
\hline $\begin{array}{l}\mathrm{J} \\
\mathrm{a} \\
\mathrm{r} \\
4\end{array}$ & $\begin{array}{l}\mathrm{Al}_{2} \text { (SO } \\
4)_{3} \text { in } \\
\mathrm{ml}\end{array}$ & 2580 & 2030 & $21 \%$ & 1747 & $\mathrm{~N} / \mathrm{A}$ & $\mathrm{N} / \mathrm{A}$ \\
\hline
\end{tabular}

Due to the large number of essays evaluated, a summary of the essays that showed a turbidity reduction of $80 \%$ or more is presented in table 10 . From the analysis of the results of this table, it can be concluded that many of the tested alternatives presented technical viability for be applied in a potato processing company. It is also observed in this table that using a lower mass of MO (Moringa Oleifera) and a lower energy expenditure with rotation, it was also possible to reach high values of efficiency. An example that proved to be quite satisfactory was the one obtained by using the moringa in direct application referring to essay 3, where it was possible, with a smaller amount of moringa mass, lower expenses with solution and energy preparation for clarification processes almost $86 \%$ removal was obtained. The fifth trial, even though it had the highest removal efficiency, used a higher MO (Moringa Oleifera) mass, requiring even a larger tree planting area to meet the treatment demand and requiring higher energy expenditure with the Fast and Slow Mixing process.

Table 10: General Summary of the highest efficiency essays.

\begin{tabular}{|c|c|c|c|c|c|}
\hline $\begin{array}{l}\text { Es } \\
\text { sa } \\
\text { y }\end{array}$ & Coagulant & $\begin{array}{l}\text { Coagulant } \\
\text { Volume/Mas } \\
\mathrm{s} \mathrm{ml} \\
\end{array}$ & $\begin{array}{l}\text { MO (Moringa Oleifera) } \\
\text { mass in coagulant } \\
\text { preparation }\end{array}$ & $\begin{array}{l}\text { Turbidity } \\
\text { Removal } \\
\text { Efficiency }\end{array}$ & Methodology \\
\hline \multirow{2}{*}{2} & \multirow{2}{*}{$\begin{array}{l}\text { Saline solution } \\
\text { in } \mathrm{ml}\end{array}$} & 10 & \multirow{2}{*}{3} & $80.12 \%$ & \multirow{5}{*}{$\begin{array}{l}\text { Fast Mix: } 200 \text { RPM for } 1 \mathrm{~min} \text {; Slow Mix: } \\
100 \text { RPM for } 40 \text { minutes }\end{array}$} \\
\hline & & 20 & & $82.40 \%$ & \\
\hline \multirow[b]{3}{*}{3} & Saline solution & 40 & \multirow{2}{*}{6} & $82.73 \%$ & \\
\hline & in ml & 60 & & $82.92 \%$ & \\
\hline & $\begin{array}{l}\text { MO (Moringa } \\
\text { Oleifera) ground } \\
\text { in g }\end{array}$ & 8 & - & $85.76 \%$ & \\
\hline 5 & $\begin{array}{l}\text { Saline solution } \\
\text { in } \mathrm{ml}\end{array}$ & 50 & 15 & $93.64 \%$ & $\begin{array}{l}\text { Fast Mix: } 480 \text { RPM rotation for } 60 \\
\text { seconds; Slow Mix: Spin at } 54 \text { RPM for } 10 \\
\text { minutes; }\end{array}$ \\
\hline
\end{tabular}

\section{MO (Moringa Oleifera) planting area required for application in a potato processing industry}

Table 11 presents the results of seed mass, number of trees and cultivation area needed to meet the demand for effluent treatment of the potato processing plant from which the effluents were collected, in Maria da Fé, Minas Gerais.

Table 11: MO (Moringa Oleifera) Required Planting.

\begin{tabular}{|l|l|l|}
\hline Required Moringa Mass & 54750 & $\mathrm{~kg} / \mathrm{year}$ \\
\hline Number of trees & 2281.25 & Trees \\
\hline Planting Area & 11406.25 & $\mathrm{~m}^{2}$ \\
\hline
\end{tabular}

It was found that the small value of required area obtained, is just over 1 ha (1.14 ha). The cost of land for planting in Brazil varies between 1,000 and 10,000 USD/ha, demonstrating that investments for planting MO (Moringa Oleifera) for coagulant production in the industry studied are not high. As previously explained, the city studied has 7 potato processing factories producing a variety of products, which indicates 
the possibility of a joint plan between the owners of the city's factories for joint planting of MO (Moringa Oleifera) even assisted by the municipal public agency, seeking to act as an environmental compensation to the city, repairing the environmental damage caused by its actions. The sludge generated by the treatment via MO (Moringa Oleifera) is biodegradable and can be used on the MO (Moringa Oleifera) plantations themselves. Third party investment for seed production for coagulant production and sale to factories is also a plausible option that can become a vector of income, jobs and development in the still-dependent city and region.

\section{CONCLUSIONS}

The present document evaluated the efficiency of the potato processing industry effluent treatment using Moringa Oleifera-based coagulants. Several combinations of coagulant preparation modes, MO (Moringa Oleifera) concentration and coagulant volume were tested to obtain the best treatment to be applied in a real factory.

Several essays showed high turbidity reduction, and one of the main uses is the use of $8 \mathrm{~g}$ of crushed Moringa seed ( $86 \%$ turbidity removal) and $50 \mathrm{ml}$ saline prepared with $15 \mathrm{~g}$ of seed, passing the solution through the filter and correcting the $\mathrm{pH}$ of the samples (93\% of turbidity removal), and the first option consumes approximately half of the seeds required for saline preparation. In the case of saline solution, the removal of BOD (Biochemical Oxygen Demand) and COD (Chemical Oxygen Demand) was above 80\%, a value that meets the minimum reduction values established by Brazilian legislation (60\%). The commercial iron and aluminum based coagulants tested showed no efficiency in the effluent treatment.

The application of MO (Moringa Oleifera) for treatment of effluents from the processing industry of the studied coat requires a small area (just over 1 ha), which makes it possible to plant MO (Moringa Oleifera) for coagulant production. Due to the large number of potato processing factories in the city studied (7), several opportunities could arise from planting MO (Moringa Oleifera) for the city, such as partnerships between city hall and industries, job creation, income and improved water bodies quality.

The wide diversity of essays and methodologies provides a comprehensive database for decision making and application of MO (Moringa Oleifera) coagulants in potato processing industries, not only in factories in the region studied, but around the world. Especially in developing countries dependent on the agricultural sector, such as Brazil, the use of MO (Moringa Oleifera) coagulants may be a good option for low cost treatment of solid and organic material effluents from the potato processing industry without $\mathrm{pH}$ change of the final effluent, contributing to the water quality of the springs of these countries, generating also a biodegradable sludge that can be used as fertilizer.

ACKNOWLEDGEMENTS: The authors also would like to thank the Brazilian National Council for Scientific and Technological Development (Conselho Nacional de Desenvolvimento Científico e Tecnológico, CNPq; in Portuguese), for granting productivity in research scholarship to Professor Regina Mambeli Barros. 


\section{REFERENCES}

AGRIANUAL. Anuário da Agricultura Brasileira. São Paulo: FNP, 2015.

ARANTES, C. C.; RIBEIRO, T. A. P.; PATERNIANI, J. E. S.. Processing of Moringa oleifera seeds using different equipments to obtain coagulant solution. Rev. Bras. Eng. Agric. Ambient, v.16, p.661-666, 2012.

AYERZA, R.. Seed and oil yields of Moringa Oleifera variety periyakalum-1 introduced for oil production in four ecosystems of South America. Industrial Crops and Products, v.36, p.70-73, 2012.

CARDOSO, K. C.; BERGAMASCO, R.; COSSICH, E. S.; MORAES, L. C. K.. Otimização dos tempos de mistura e decantação no processo de coagulação/floculação da água bruta por meio da Moringa oleífera Lam. Acta Scientiarium Technology, v.30, n.2, 2008.

CARVALHO, W. T.. Secagem de Polpa Residual Obtida na Industrialização de Batata Frita. Dissertação (Mestrado em Engenharia de Alimentos) - Universidade Federal de Goiás, Goiânia, 2012.

SILVA, H. L. C.; SILVA, F. S.; GIMENES, R.; KONDO, M. M.; SILVA, M. R. A.. Tratamento de efluente de indústria de processamento de batata por processo foto-Fenton heterogêneo utilizando ferrita de pilhas descartadas. Eclética Química Journal, v.41, p.101-111, 2016.

CONAMA. Conselho Nacional do Meio Ambiente. Resolução n. 430 de 13 de maio de 2011. Brasília: CONAMA, 2011.

PAULA, H. M.; ILHA, M. S. O.; ANDRADE, L. S.. Concrete plant wastewater treatment process by coagulation combining aluminum sulfate and Moringa oleífera powder. Journal of Cleaner Production, v.76, p.125-130, 2014.

FERNANDES, D. M.; SQUISSATO, L. A.; LIMA, A. F.; RICHTER, E. M.; MUNOZ, R. A. A.. Corrosive character of Moringa oleifera Lam biodiesel exposed to carbon steel under simulated storage conditions. Renewable Energy, v.139, p.1263-1271, 2019.

HADJIVASSILIS, I.; GAJDOS, S.; VANCO, D.; NICOLAOU, M.. Treatment of wastewater from the potato chips and snacks manufacturing industry. Water Science and Technology, v.36, p.329-335, 1997.

HUNG, Y. T.; LO, H. H.; AWAD, A.; SALMAN, H.. Potato Wastewater Treatment. In: WANG, L. K.; HUNG, Y. T.; LO, H. H.; YAPIJAKIS, C.. Waste Treatment in the Food Processing Industry. Taylor \& Francis Group, LLC, 2006.

JUNHO, A. L.; SANTOS, I. F. S.; SILVA, A. L.; SANT'ANNA, D. O.; BARROS, R. M.. Treatment of wastewater from the dairy industry with Moringa Oleífera using two different methods. Article accepted to Journal of Research, Society and Development. 2021.

KAYODE, R. M. O.; AFOLAYAN, A. J.. Cytotoxicity and effect of extraction methods on the chemical composition of essential oils of Moringa oleifera seeds. J. Zhejiang Univ. Sci. B, v.16, p.680-689, 2015.
KOBYA, M.; HIZ, H.; SENTURK, E.; AYDINER, C.; DEMIRBAS, E.. Treatment of potato chips manufacturing wastewater by electrocoagulation. Desalination, v.190, p.201-211, 2006.

LIU, Y.; WANG, X. Y.; WEI, X. M.; GAO, Z. T.; HAN, J. P.. Values, properties and utility of different parts of Moringa oleifera: An overview. Chinese Herbal Medicines, v.10, p.371-378, 2018.

MONACO, P. A. V. L.; MATOS, A. T.; RIBEIRO, I. C. A.; NASCIMENTO, F. S.; SARMENTO, A. P.. Use of extract of moringa seeds as coagulant agent in treatment of water supply and wastewater. Ambiente \& Agua: An Interdisciplinary Journal of Applied Science, v.5, n.3, p.222231, 2010.

MADRONA, G. S.; BRANCO, I. G.; SEOLIN, V. J.; ALVES FILHO, B. A.; KLEN, M. R. F.; BERGAMASCO, R.. Evaluation of extracts of Moringa oleifera Lam seeds obtained with $\mathrm{NaCl}$ and their effects on water treatment. Acta Scientiarum Technology, v.34, n.3, p.289-293, 2012.

MAKWANA, A. R.; AHAMMED, M. M.. Continuous electrocoagulation process for the post-treatment of anaerobically treated municipal wastewater. Process Safety and Environmental Protection, v.102, p.724-73, 2016.

MOURA, L. S.. Viabilidade da implantação de decanter centrífugo para redução de consumo de água em linha de produção de batata frita. Especialize On-Line IPOG. 5 ed. Goiânia, 2013.

CORRÊA, M. P.. Dicionário das plantas úteis do Brasil e das exóticas cultivadas. Rio de Janeiro: IBDF, 1984.

NDABIGENGESERE, A.; NARASIAH, K. S.; TALBOT, B. G.. Active agents and mechanism of coagulation of turbid waters using Moringa oleifera. Water Research, v.29, n.2, p.703-710, 1995.

PRICE, M. L.; DAVIS, K.. The moringa tree. Echo technical note. Publicado em 1985, revisado em 2000. Echonet, 2020.

RADEEF, A. Y.; ISMAIL, Z. Z.. Polarization model of microbial fuel cell for treatment of actual potato chips processing wastewater associated with power generation. Journal of Electroanalytical Chemistry, v.836, p.176-181, 2019.

RANGEL, M. S. A.. Moringa oleifera; uma planta de uso múltiplo. Embrapa-CPATC, Tabuleiros Costeiros. Circular Técnica. Aracaju, 1999.

ROCHA, V. V. F.; SANTOS, I. F. S.; SILVA, A. M. L.; SANT'ANNA, D. O.; JUNHO, A. L.; BARROS, R. M.. Clarification of highturbidity waters: a comparison of Moringa oleifera and virgin and recovered aluminum sulfate-based coagulants. Environment, Development and Sustainability, v.1, p.1-12, 2019.

SILVA, M. E. R.; AQUINO, M. D.; SANTOS, A. B.. Póstratamento de efluentes provenientes de reatores anaeróbicos tratando esgotos sanitários por coagulantes naturais e não-naturais. Revista Tecnologia, v.28, n.2, p.179, 2007. 
TFOUNI, S. A. V.; MACHADO, R. M. D.; GARCIA, L. C.; AGUIRRE, J. M.; GASPARINO, F. J.. Batata chips e palha. Campina, n.3, p.73, 2003.

TIKARIHA, A.; SAHU, O.. Study on characteristics and treatment of dairy industry wastewater. Journal of Applied \& Environmental Microbiology, v.2, n.1, p.16-22, 2014.

VALVERDE, K. C.; MORAES, L. C. K.; BONGIOVANI, M. C.; CAMACHO, F. P.; BERGAMASCO, R.. Coagulation diagram using the moringa oleifera lam and the aluminium sulphate, aiming the removal of color and turbidity of water. Acta Scientiarum Technology, Maringá, v.5, n.3, p.485-489, 2013.

VIEIRA, A. M. S.; VIEIRA, M. F.; SILVA, G. F.; ARAÚJO, A. A.; KLEN, M. R. F.; VEIT, M. T.; BERGAMASCO, R.. Use of moringa oleifera seed as a natural adsorbent for wastewater treatment. Water, Air, and Soil Pollution, v.206, n.1-4, p.273-281, 2009.

VILLASEÑOR-BASULTO, D. L.; SÁNCHEZ, P. D. A.; OLVERA, J. D. R.; BANDALA, E. R.. Wastewater treatment using Moringa oleifera Lam seeds: A review. Journal of Water Process Engineering, v.23, p.151-164, 2018.

WALKER, C.; BERETTA, C.; SANJUÁN, N.; HELLWEG, S.. Calculating the energy and water use in food processing and assessing the resulting impacts. International Journal Life Cycle Assessment, v.23, p.824-839, 2018.

ZOUTBERG, G. R.; EKER, Z.. Anaerobic treatment of potato processing wastewater. Water Science and Technology, v.40, p.297-304, 1999.

A CBPC - Companhia Brasileira de Produção Científica (CNPJ: 11.221.422/0001-03) detém os direitos materiais desta publicação. Os direitos referem-se à publicação do trabalho em qualquer parte do mundo, incluindo os direitos às renovações, expansões e disseminações da contribuição, bem como outros direitos subsidiários. Todos os trabalhos publicados eletronicamente poderão posteriormente ser publicados em coletâneas impressas sob coordenação da Sustenere Publishing, da Companhia Brasileira de Produção Científica e seus parceiros autorizados. Os (as) autores (as) preservam os direitos autorais, mas não têm permissão para a publicação da contribuição em outro meio, impresso ou digital, em português ou em tradução. 